
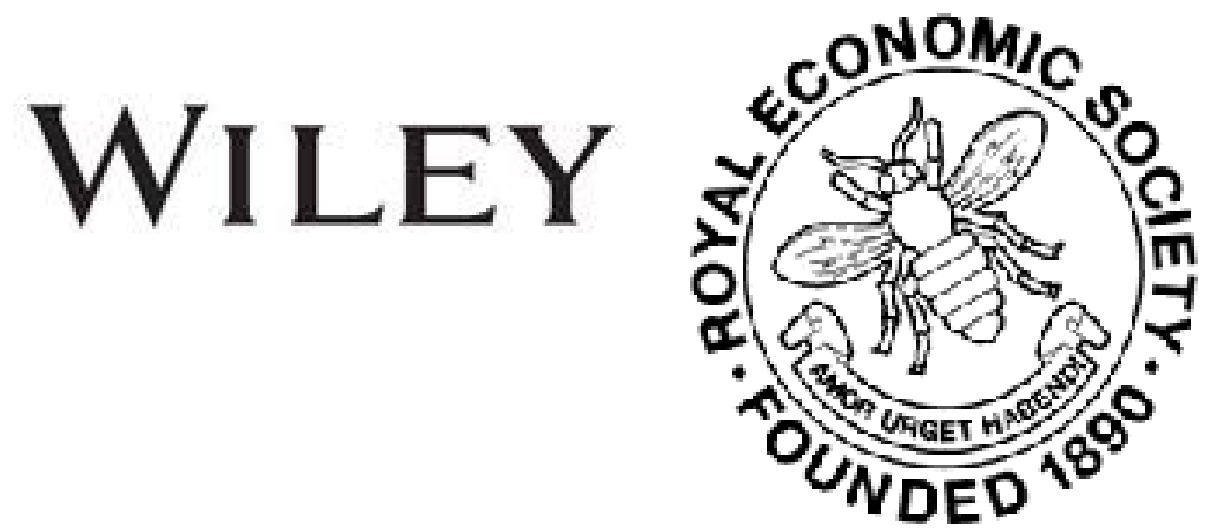

The Unity of Political and Economic Science

Author(s): A. C. Pigou

Source: The Economic Journal, Vol. 16, No. 63 (Sep., 1906), pp. 372-380

Published by: Wiley on behalf of the Royal Economic Society

Stable URL: http://www.jstor.org/stable/2220810

Accessed: 27-06-2016 02:27 UTC

Your use of the JSTOR archive indicates your acceptance of the Terms \& Conditions of Use, available at

http://about.jstor.org/terms

JSTOR is a not-for-profit service that helps scholars, researchers, and students discover, use, and build upon a wide range of content in a trusted digital archive. We use information technology and tools to increase productivity and facilitate new forms of scholarship. For more information about JSTOR, please contact support@jstor.org.

Wiley, Royal Economic Society are collaborating with JSTOR to digitize, preserve and extend access to The Economic Journal 


\section{THE UNITY OF POLITICAL AND ECONOMIC SCIENCE $^{3}$}

$\S 1$. One part of the knowable world is human society. The science of society is systematised knowledge of society as a causally connected whole. It is divisible into departments, though it is itself more than the sum of these. The departments deal with society in various aspects, chief among which are the religious, the political, and the economic. In all of these the centre is man. It is not, indeed, in him that ultimate explanations lie, for man himself is unexplained. But the science of society, in its process from cause to cause, stops at the gateway of philosophy. To explain in terms of human volition completes its humbler task. For it, " les seules changements importants . . . s'opèrent dans les idées, les conceptions et les croyances. Les évènements mémorables de l'histoire sont les effets visibles des invisibles changements de la pensée des hommes." 2 The causes that it seeks reside, as Bentham held, in mental facts, though not, of course, as he also held, in mere pleasure and pain. This is true of all departments of the science of society. Mind is the root in which they all begin. From it they grow and spread, and assume a multitude of forms. Various, however, as these appear, the unity of origin carries with it a unity of essential structure. It is this unity, as between the political and economic branches of social science, that my paper seeks to display.

$\S 2$. In the first place, the mental facts that underlie both sciences are similar. They are the whole body of desires and aversions, including, of course, the desire for right and the aversion to wrong-doing. This resemblance is general. Within it there fall others that are more particular. The determining desires are mixed as regards, on the one hand, egoism

1 The analogy worked out in this paper was roughly suggested in my note $A$ Parallel between Economical and Political Theory in the Economio Jodrnal for June, 1902.

${ }^{2}$ Le Bon : La psychologie des foules, p. 2. 
and altruism, on the other, means and ends. First, in both departments they are partly self-regarding and partly extra regarding. Just as some persons desire tea for their own use and others for purposes of charity, so some desire the passage of a law with a view to their private gain, and others because they believe that it will prove beneficial to the community as a whole. Nor are these two motives generally separated from one another and distributed among different persons; on the contrary, they are almost invariably blended. Secondly, in both cases the object desired may be desired either as means, or as end, or partly as one and partly as the other. Thus, an economic acquisition may be sought chiefly for its indirect use in facilitating the passage of a law, or a law for the help it will give toward the gratification of economic aims.

Furthermore, the desire for a particular commodity or law is not necessarily dependent upon the circumstances of that object alone. It may, indeed, be thus self-sufficing, but it is more likely to be some function of the supply of other commodities or laws that serve as complements to, or substitutes for it. For example, the desire for tea depends partly on the quantity of sugar available, and the desire for a law against duelling on the existence of an adequate provision of legal tribunals.

$\S 3$. In the second place, in both departments, desires do not operate upon events directly. Before ideas can become forces they must be translated into effective demand. Effective demand, however, is not based merely on desire, nor is its intensity proportionate to that of the desire. In economics it means, as everybody knows, desire for a commodity or service conjoined with the possession of purchasing power. In politics it means desire for the passage of a law conjoined with the means of influencing the legislative machine. These means consist partly in the reserve power of physical force, whereby a real control may be exercised over a government legally quite independent of the classes concerned. $^{1}$ In a democratic country, in ordinary times, they are broadly equivalent to voting power.

The effective demand of the community, which is, of course, the operating force, is compounded from the demands of the separate members. It is not, however, necessarily compounded by mere summation, for the parts may be mutually dependent on one another. Thus, in economics the demand of A may be partially dependent on the quantity of commodity possessed by

1 Dicey shows that Walpole's administration was pliable to this type of influence from classes not possessed of the franchise (Law and Opinion, p. 11). 
$B$ and vice versâ, so that mere summation would be fallacious. ${ }^{1}$ Similarly, in politics, the opinion of an assemblage of persons may be quite different from-sometimes superior, sometimes inferior to-the sum of the opinions of the individuals assembled. In economic and political theory alike, "We should not yield ourselves to the illusion that the individual is fitted up with his essentials all by himself, and that then society is constituted by the aggregation of such single specimens. The individual is, in fact, the later product; and disengages himself into his independent wholeness as the ripest fruit of a collective development." ${ }_{2}$

The last point need not, perhaps, be pressed. From the general relation between desire and effective demand there follow, however, two important conclusions. The first is that, even where desires remain unaltered, the demand built on these desires may be modified. In economics this occurs when the wealth of the various classes in the community is varied; in politics when the constitutional machine is reformed so as to extend or otherwise remodel the franchise. In economics changes of this kind are gradual. In politics, in the absence of automatic schemes for the redistribution of seats, such as have been introduced into Australasia and the Transvaal, they are abrupt.

The second conclusion that follows is that, when the desire for any given commodity or law rises, the effective demand for it need not rise, unless the desire for other commodities or laws has not risen. If these have risen, the increase of intensity among them may draw off so much of the available money or political energy, that the given desire, despite its own increase, may be manifested in an effective demand actually smaller than before.

\$4. In economics and politics alike Demand calls out Supply. In the one case the suppliers are the producers of goods and services; in the other, they are the wielders of the legislative machine. No doubt the object supplied is different in the two cases. In economics it is usually divisible into small units. In politics, however, a law is in general either passed or not passed. It is true that local option and contractingout clauses are sometimes introduced; but, even with these, there is a substantial difference between the large packets in which legislative goods are supplied and the marginal increments familiar to economic theory. This difference leads to an important distinction between the significance of the phrase "Demand calls out Supply," as used in the two spheres. In economics it means

${ }^{1}$ Cf. my paper-Some Remarks on Utility, Economic Jounnay.

2 Martineau, Types of Ethical Theory, 11, 32. 
that an increase of demand causes a greater quantity of the commodity to be supplied. In politics, however, since the commodity is a single unit, this quantitative relation does not subsist. Rather, the object is either produced or not produced according as the demand is above or below a certain level. Demand calls out supply when, by rising beyond that level, it brings the object into being. In politics, therefore, the ultimate adjustment is much rougher than in the generality of economic problems.

$\$ 5$. Though, however, the goal of adjustment differs in these respects, there is a striking similarity in the route by which it is reached. In the first place, in economics and politics alike supply invariably lags behind demand. In the one it is a commonplace that supply often reaches its maximum when the tide of demand has been for some time on the ebb. In the other " it may well happen that an innovation is carried through at a time when the teachers who supplied the arguments in its favour are in their graves, or even-and this is well worth noting-when in the world of speculation a movement has already set in against ideas which are exerting their full effect in the world of action and legislation." 1

In the second place, the factors that determine the extent of the lagging are very similar in the two spheres. In economics this lagging is least in regard to commodities the natural machinery for whose production can be readily altered in amount and character. In politics it is least when the moral machinery for effecting legislative change can be readily adapted or renewed. The degree of readiness depends in both cases partly on the physical construction of the machinery and partly on the other uses in which it is liable to be employed.

Physical construction is, of course, important. In economics it is obvious that simple machinery can be constructed more rapidly than complex, and that, therefore, the supply of those commodities that are made with simple machines will lag least behind demand. In politics, again, anything in the nature of a caste system, or a traditionary reverence for governing families, or long terms of appointment for legislators greatly extends the time required to make machinery capable of supplying the new demand. On the other hand, institutions that provide for frequent elections or other forms of appeal to the people lessen the time required.

The extent of the interval of lagging does not, however, depend solely on the way in which the machinery of supply is constituted. It is also increased in respect of any object if that machinery is also

1 Dicey, Law and Opinion, p. 17. 
employed for other purposes, and is, therefore, modified with only partial reference to the requirements of the given object.

Thus, in economics, since mutton and wool are supplied jointly, a given change in the demand for wool will affect production more slowly than it would do if that commodity were produced in isolation. For the full effect of the change cannot be developed till the connection between wool and mutton has been ruptured by a modification in the breed of sheep.

This circumstance is exactly paralleled in the political sphere. Under the Cabinet system a demand for a particular piece of legislation may remain for a long time unsatisfied because the politicians who would be willing to supply it are also pledged to supply something else to which public opinion is averse. Hence, until the demand has evoked a new type of politician, willing both to supply it and to refrain from supplying the unpopular accompaniment, no effect is likely to be produced.

Whatever weakens the connection between one commodity and another on the side of supply tends to diminish the interval of lagging in both spheres. The connection is dependent upon the fixity, in the one case of physical, in the other of mental conditions. In politics it may be weakened by the introduction of the Referendum or Initiative, involving a separation of the supply of particular laws from that of a party's general programme. It is also weakened by the creation of independent departments within the Government, the separation, for example, of the Judiciary from the Legislature, and of both from the Executive, or the separation of one minister from another by the abandonment of Cabinet solidarity.

In both economics and politics, however, powerful forces are opposed to any disruption of joint supplies. In economics it is often profitable to produce two commodities together, even when it is physically possible to separate them. Similarly, in politics unity of control often secures a great saving of labour and increase of efficiency. The combination of administrative and legislative functions in the same hands has advantages of this order. It is often said, for example, that the laws are likely to be better when those who initiate know that they will themselves be called upon to execute them. It may well be, therefore, that, despite of the lagging it involves, combined supply is often the method most satisfactory on the whole.

$\$ 6$. So long as the lagging lasts, existing firms and ministers in power occupy a position of independence over against demanders. If the legislators were so many separate suppliers of 
law, their economic counterpart would be a group of independent concerns in the enjoyment of quasi-rent. In fact, the governing body is, as a rule, a unity, and its analogue is the industrial combine exercising the privileges of a temporary monopoly.

For the short periods during which their monopoly power continues, the controllers of supply are free to act either (1) in their own personal interests, sacrificing thereto the interest, in economics, of the shareholders, in politics of their country ; or (2) in the interests of the said shareholders or country exclusively; or (3) in the interests partly of their constituents and partly, in economics, of the general public, in politics, of the community of nations. They are not, indeed, entirely free to choose between these courses. Their constituents generally employ some scheme of checks and balances, whether the representative system or some other device, for limiting so far as possible the extent to which their own interests are imperilled. Considerable freedom, however, is likely to remain.

Within the limits set to them, the controllers of supply can act directly upon the amount of supply, and, by this means, promote whichever of the above three interests they elect to favour. Furthermore, in the exercise of this power they can often modify future conditions of demand. In economics manufacturers can create or develop a taste for their wares by selling them cheap for a little while. This is, of course, often done by railway companies in the hope of profit, and sometimes by philanthropists in the hope of developing the artistic capacities of the people. In politics Cabinets, by supplying laws that are not wanted at the moment, can cause them to be wanted afterwards. Of this there are many instances. Thus Mr. Booth writes :"The attempts made by special legal enactment to stamp their true character on unscrupulous money-lending, on secret commissions, and on fraud in company promotion, though very difficult of execution, have undoubtedly had a considerable effect on public opinion." 1 Again, Professor Dicey has explained how English factory legislation, begun from humanitarian motives with the favour of the individualist school, indirectly assisted the development of collectivist views. "The history of the factory movement," he says, "is itself sufficient proof that laws may be the creators of legislative opinion." ${ }_{2} \mathrm{He}$ finds illustrations of the

1 Life and Labour, xvii. 211-212.

2Law and Opinion, p. 237. By reference to the law of married women's property, he illustrates further how the judiciary, by judge-made law, have moulded opinion in a way that has afterwards affected legislation (p. 396, etc.), 
same character in the history of the English Reform Acts, marriage laws, and Education Acts. ${ }^{1}$

This reflex influence of supply upon demand, besides indicating the great responsibility of legislators and merchants, serves partly to explain the large measure of continuity that prevails in the production alike of commodities and of legislation. The supply of a commodity once undertaken is not readily dropped, partly indeed for fear of the loss involved in scrapping plant, but partly because, when consumers have accustomed themselves to the commodity, their demand for it is by that very fact rendered more extensive than it was before. In like manner in politics, when a measure has been passed, the community adapts itself to the new conditions. The loss and disturbance involved in repeal would therefore be much greater than any that could have followed from a refusal to pass it in the first instance. The Chinese Labour Ordinance of the Transvaal is a case in point. In the same way, custom avails to establish the position of a minister who has once, perhaps quite independently of general opinion, been raised by the Prime Minister to front bench rank.

Nor is the influence which suppliers may exercise on demand limited by their power of actually producing some object and exhibiting it as a model for popular instruction. A similar effect may be brought about by advertisement. By this means demand can be created without any preliminary experimental supply. The method, so far as it affects the economic sphere, needs no comment. In the political sphere its analogue is found in an agitation by some leading politician, a member, for instance, of the Inner Cabinet. In this way it is always possible that a proposal, hitherto regarded as academic, may be brought into the sphere of " practical politics." Prominent illustrations are Gladstone's conversion to Home Rule and Mr. Chamberlain's repudiation of Free Trade. In both these cases demand was profoundly modified by the action of the controllers of supply.

Finally, in economics and politics alike, there are cases in which the suppliers cannot actually alter the character of demand, but can take advantage of the fluctuations which naturally occur in it. In the case of durable commodities owners can hold up their supply till such time as they think the demand has reached its highest and then offer to sell. This is done in land speculation, and also, for short periods, in the marketing of seasonal articles like cotton. Under the English Parliamentary system an exactly similar power is wielded by Ministers. For, subject to the Sep-

\footnotetext{
1 Law and Opinion, pp. 41-6.
} 
tennial Act, they are free to determine the date at which they will dissolve Parliament. As Mr. Low observes, they are thus enabled to "find the sovereign people" at the moment when they have reason to expect that their chances of success are greatest.

This policy in reference to demand is not open to manufacturers of commodities that are perishable, and for which, therefore, the time of sale is fixed independently of their will. Nor is it open to politicians when the period of appeal to the country is independently fixed, whether, as in the United States, by a rigid time limit or by some more elastic reference to bye-elections or the will of a monarch.

$\S 7$. The essential unity of political and economic science has so far been traced along the lines of accepted analysis. In conclusion it is interesting to note that it extends also to the chief fallacy of the two sciences. This is the famous doctrine of Maximum Satisfaction. In economics that doctrine affirms that complete industrial and commercial freedom conduce to the greatest possible sum of economic good; in politics that complete political freedom, or, in other words, pure democracy, conduces to the greatest possible sum of legislative good. In both cases the argument is fundamentally the same. In economics its formulation generally turns upon " demand and supply," in politics upon the "general will." In both it finally reduces to the thesis that, since each man, if left free, will best advance his own interests, therefore all men, if left free, will best advance the interests of all, ${ }^{1}$ provided, of course-and this reservation is made in both spheres - that the operation of force and fraud is excluded. This argument is incorrect at once in its premiss and in its inference.

First consider the premiss. The word " interest" is ambiguous. It may be true that an individual is the best judge of his interest, when by interest is meant what he as a matter of fact does want, but it is not true that he is the best judge of what he ought to want. This point is admirably brought out by the late Professor Sidgwick. "The principle, 'Love thy neighbour as thyself,' might," he writes, "when it has attained general acceptance and serious efforts are made to fulfil it-be advantageously supplemented by the converse precept, love thyself as thy neighbour, since a genuine regard for our neighbour, when not hampered by the tyranny of custom, prompts us to give him what we think really good for him, whereas natural self-regard prompts us to give

${ }^{1}$ Cf. Dicey's citation from Maine, p. 158. 
ourselves what we like. Thus the spontaneous expression of altruism, rather than the spontaneous expression of egoism, corresponds to our deepest judgment, the judgment of our best self, as to the good or evil in human life." 1 Even, therefore, if it were true that the freedom of each did conduce to a maximum satisfaction of the desires of all, it would not follow that it conduced to their maximum good or true satisfaction. This conclusion is obviously applicable to both economics and politics.

Secondly, the argument is erroneous in its inference. It is not true that the conjoint pursuit by each of his individual interest necessarily tends to forward the general interest. For-apart from the formal failure of such an inference-desires are not in general commensurate with the power of securing their fulfilment. In economics very various intensities of desire may be represented by equal demand prices, owing to variations either in the purchasing power of different persons, or in the temperament of persons of equal purchasing power. It cannot, therefore, be argued that, because free competition maximises apparent satisfaction in terms of money, it must maximise real satisfaction. In political democracy the analogue of purchasing power, namely, voting power, is indeed equal for all; but the disharmony due to variations of temperament among the citizens remains. The demand of a person who desires a particular law very little is as effective as that of one who desires it very much, and the aversion of a majority, merely because it is a majority, may nullify a much more intense desire on the part of a minority. The doctrine of Maximum Satisfaction thus fails in much the same way in each of the two sciences.

\section{A. C. Pigov}

1 Practical Ethics, p. 210. Professor Sorley suggests that the root of this divergence may lie in the circumstance that " the individual takes as the guide of his own action the egoistical qualities which give success in the struggle between different individuals, but recommends to all his fellows in the same community that they should cultivate those altruistic qualities which will lead to the advantage of society." (Recent Tendencies in Ethics, p. 75.) 